\title{
ELECTRIC CIGARETTES'S EFFECT TO THE MDA LEVELS IN BLOOD OF WISTAR RAT
}

\author{
Ftha Rambung1) \\ ${ }^{1}$ Fakultas Kedokteran Universitas Ciputra Surabaya \\ Email : etha.rambung@ciputra.ac.id
}

\section{Submitted: 05-02-2020, Reviewer: 07-02-2020, Accepted: 08-02-2020}

\begin{abstract}
The use of electronic cigarettes (e-cigarettes) has spread widely and increased dramatically among young people aroud the world. Variations in product design, taste, and marketing patterns increase the young people's interest in electronic cigarettes. Even many electric cigarettes are sold in shoppinng cebters and online, so they are easy to reach by teenagers. This study aims to analyze oxidative stress due to exposure to e-cigarettes by assessing the difference in blood MDA levels in the control and treatment groups. The method used is the Posttest Only Control Group Design. Thirty two male wistar rats divided into four treatments goups: K1 (SC(-), EE (-)), K2 (SC(-), EE(-)), P1 (SC(-), EE(+) 15 times), and P2 (SC (-), EE (+) 30 times). The treatment is given for 5 minutes/ day for 50 days. Termination was carried out on the $50^{\text {th }}$ day using ketamine. Intracardial blood sampling for examination of MDA levels by the TBARS method. The data obtained were tested by Kruskal Wallis with a significance of $p<0.05$. MDA blood levels in P2 were significantly higher than P1 $(p=0,035), K 2(p=0,001)$ and $K 1(p=0,001)$. This study shows that e-cigarettes can cause oxidative stress in experimental animals.
\end{abstract}

Keywords: E-cigarettes, Oxidative stress, MDA level

\begin{abstract}
ABSTRAK
Penggunaan rokok elektrik (e-cigarette) telah menyebar luas dan meningkat secara dramatis di kalangan anak muda di seluruh dunia. Variasi desain, rasa, dan pola pemasaran meningkatkan daya tarik ecigarette bagi kaum muda. Bahkan banyak e-cigarette dijual di toko-toko dan online, sehingga mudah dijangkau oleh remaja. Penelitian ini bertujuan untuk menganalisis stres oksidatif akibat paparan ecigarette dengan menilai perbedaan kadar MDA darah pada kelompok kontrol dan perlakuan. Metode yang digunakan adalah Posttest Only Control Group Design.. Tiga puluh dua tikus wistar jantan dibagi menjadi empat kelompok perlakuan: K1 (SC(-), EE(-)), K2 (SC(-),EE(-)), P1 (SC(-), EE(+) 15 kali ), dan P2 (SC (-), EE (+) 30 kali). Perawatan diberikan selama lima menit / hari selama 50 hari. Pengakhiran dilakukan pada hari ke-50 menggunakan ketamin. Pengambilan sampel darah secara intracardial untuk pemeriksaan kadar MDA menggunakan metode TBARS. Hasil analisa statistik data yang diperoleh dengan uji Kruskal Wallis menunjukkan signifikansi $p<0,05$. Kadar MDA darah dalam P2 secara signifikan lebih tinggi dari P1 $(p=0,035), K 2(p=0,001)$ dan $K 1(p=0,001)$. Studi ini menunjukkan bahwa e-cigarette dapat menyebabkan stres oksidatif pada hewan percobaan.
\end{abstract}

Keywords: Rokok elektronik, Stres oksidatif, Kadar MDA 


\section{INTRODUCTION}

Electronic cigarette are those used to produce steam containing nicotine. This electronic cigarette uses batteries as its energy source (Grana, 2013). Electronic cigarettes heats liquids that contain nicotine into aerosols. Electronic cigarette users breathe this aerosol. Aerosols contain chemicals that are toxic and non-toxic. These include propylene glycol (PG), nicotine, vegetable glycerin $(\mathrm{VG})$, and other flavoring ingredients. These substances are in the form of droplets and gases (Alexander et al., 2015).

Electronic cigarettes have spread widely to almost all circles, including teenagers, since it was introduced in 2007. Sales of electronic cigarettes were reported to have increased by 14 times from 2008 to 2017 (Qasim et al., 2017). The use of electronic cigarettes in the United States has increased from year to year. The use of electronic cigarettes in 2009 was $0.6 \%$, in 2010 it increased to $2.7 \%$, and in 2011 it increased again to $6.2 \%$. The use of electronic cigarettes in the UK in 2010-2013 has also increased. The use of electronic cigarettes in 2010 was $2.7 \%$, in 2012 it increased to $6.7 \%$, and in 2013 it increased again to $11 \%$ (Hajek et al., 2014). This increase in cigarette use if not treated immediately, it is estimated that by 2030 it can kill more than 8 million people per year worldwide. This is especially true for countries with low-moderate per capita income (Devhy and Yundari, 2017).

Electronic cigarette users in Indonesia also increased compared to the previous year. The number of electronic cigarette users in Indonesia in 2010-2011 was 0.5\% (Artha and Kusuma, 2017). The highest number of e-cigarette users in the Surabaya personal vaporizer community is male (96.8\%), aged 26-35 years $(54.8 \%)$, high school-college education level $(100 \%)$, has a job as an employee (71\%) and have smoked before (93.6\%) (Damayanti, 2016).
The number of young people using electronic cigarettes is increasing dramatically throughout the world. Electronic cigarettes are the main attraction for young people because the products are made as attractive as possible, the flavors offered are varied and easily obtained by them (Ferkol et al., 2018). Electric cigarettes are widely marketed as advanced technology and can be used as a safer substitute for tobacco cigarettes. Marketing uses young idol artists, posters and trendy styles. The sale of electronic cigarettes can even be found in shopping centers. Electronic cigarette sales are even done online. This makes it easy for teenagers to get electronic cigarettes, because teenagers use most of their free time in shopping centers and browsing online (Grana, 2013).

The number of high school students who already know about electronic cigarettes in 2013 was 13.1 million. The number of electronic cigarette use (usage is defined as usage for at least 1 day for the past 30 days) based on National Tobacco Youth Survey data in 2011 was $1.5 \%$. This number increased significantly in 2015 was $16 \%$. For high school students, this number exceeds the level of conventional cigarette use. This means there are 620,000 high school students, who for the past 30 days used electronic cigarettes at least once, out of a total of 2.4 million students. This is of course very worrying, so it is a subject of discussion in related environments, including health and schools. The focus of attention is the risk of addiction and the dangers of nicotine use among nonsmokers, especially teenagers (U.S. Department of Health and Human Services, 2016). A survey of high school students in Denpasar states that the use of electronic cigarettes is quite high $(20.5 \%)$. Users are generally male students (43.8\%), have used tobacco cigarettes before $(94.7 \%)$ and have friends who use electronic cigarettes (44.8\%) (Putra et al., 2018). 
Ediana's research results (2016) states that the role of housewives is related to smoking behavior in the family. The role of housewives who are not optimal shows the tendency of family members to have smoking habits as much as 3.6 times compared to family members where housewives play an optimal role (Ediana, 2016).

This study aims to analyze oxidative stress due to exposure to electronic cigarette by assessing differences in MDA levels in blood between groups that were exposed to electronic cigarettes compared with groups who were not exposed and assessing differences in MDA levels between groups given 30 sprays compared to 15 sprays of electronic cigarette.

\section{METHOD}

This laboratory experimental study uses the Postest Only Control Group Design method. The Medical Research Ethics Committee, Faculty of Medicine, University of Ciputra has approved this study (No. 051 / EC / KEPK-FKUC / 2019). The experiment and MDA levels examination is done in biochemistry Laboratory, Faculty of Medicine, Universitas Airlangga.

The rats used as experimental animal models in this study were wistar rats (Rattus norvegicus), male, 2-3 months old and weighs 150-200 grams. Rats in good health did not have macroscopic abnormalities and were not used in other studies. Rats were adapted in the laboratory for 7 days before treatment began. The number of samples was 32 rats (based on the Frederer formula). There are four groups of rats, namely $\mathrm{K} 1$, $\mathrm{K} 2, \mathrm{P} 1$ and P2. Each group consists of 8 rats. Group $\mathrm{K} 1$ is a group of rats that were not given electronic cigarette exposure: not placed in the smooking chamber (SC) and not given electronic cigarette exposure (EE) (SC (-), EE (-)).Group K2 are rats that is placed in a smooking chamber but are not given electronic cigarette exposure $(\mathrm{SC}(+)$, $\mathrm{EE}(-))$. Group P1 are rats that is placed in the smooking chamber and given electronic cigarette exposure 15 sprays of electronic cigarette (SC (+), EE (+) 15 sprays). Group $\mathrm{P} 2$ are rats that is placed in the smooking chamber and given electronic cigarette exposure 30 sprays of electronic cigarette (SC (+), EE (+) 30 sprays). Smoking chamber is a rectangular treatment cage with a size of $50 \times 42 \times 26 \mathrm{~cm}$ with a volume of 54.6 liters made of glass with two holes on the top, front and back, and one hole on the right and left side of the cage. Right side hole for exposure to electronic cigarette, while the other hole to provide circulation so that rats are not hypoxic. Electronic cigarette specifications: variable watted, type of atomizer: Rebuildable Tank Atomizer (RTA), rechargeable batteries made from lithium ion and an electronic cigarette solution containing $3 \mathrm{mg}$ of nicotine and propylene glycol (PG)/vegetable glycerin (VG) levels: 30/70. Before treatment, RTA batteries must be checked first. If the battery is lacking, the battery is charged first. Then the liquid jar is opened and filled to the full limit with the liquid that has been provided. The tube is then closed again. After that the treatment cage is prepared to start the treatment. Treatment is given for 5 minutes/ day for 50 days. After the rat treatment is put back into the maintenance cage.

After anesthetized with ketaminexylazine, intracardial blood sampling was taken as much as $3 \mathrm{cc} / \mathrm{rat}$. Examination of blood MDA levels is done using the TBARS (Thiobarbituric Reactive Acid) method. This test detects the TBA and MDA reactions that produce pink compounds. Color intensity was measured using a spectrophotometer with a wavelength of $532 \mathrm{~nm}$ or with a fluorescence intensity at $560 \mathrm{~nm}$. Quantitative data are blood MDA levels in mmol / L. Data were analyzed by the Kruskall Wallis test to see differences in 
blood MDA levels in all groups and then analyzed with Mann Whitney U to compare between groups. SPSS (statistical product and service solutions) version 23 is used to analyze the data obtained ( $\mathrm{p}<0.05$ ).

\section{RESULTS AND DISCUSSION}

The results obtained were differences in blood malondialdehyde levels in each group. The mean and differences in rat blood MDA levels are shown in table 1. The highest blood MDA level was found in the P2 group $18.77 \pm 5.76$ while the lowest group was found in the K1 group $4.58 \pm 1.27$ (Figure 1).

Table 1. Mean Value and Difference of Blood MDA levels

\begin{tabular}{ccc}
\hline Groups & $\begin{array}{c}\text { B ood MDA le vels } \\
(\mathbf{X} \pm \mathbf{S D})\end{array}$ & p value \\
\hline $\mathrm{K} 1(\mathrm{n}=8)$ & $4,58 \pm 1,27$ & $0,000^{* *}$ \\
$\mathrm{~K} 2(\mathrm{n}=8)$ & $4,85 \pm 1,53$ & \\
P1 $(\mathrm{n}=8)$ & $11,57 \pm 2,99$ & \\
P2 $(\mathrm{n}=8)$ & $18,77 \pm 5,76$ & \\
\hline
\end{tabular}

The data obtained showed that blood MDA levels were not normally distributed based on the Kolmogorov-Smirnov normality test $(\mathrm{p}<0.05)$, homogeneous data based on the Levene test ( $\mathrm{p}<0.05$ ), and had significant differences based on the KruskalWalis test showing differences significant ( $p$ $<0.05)$.

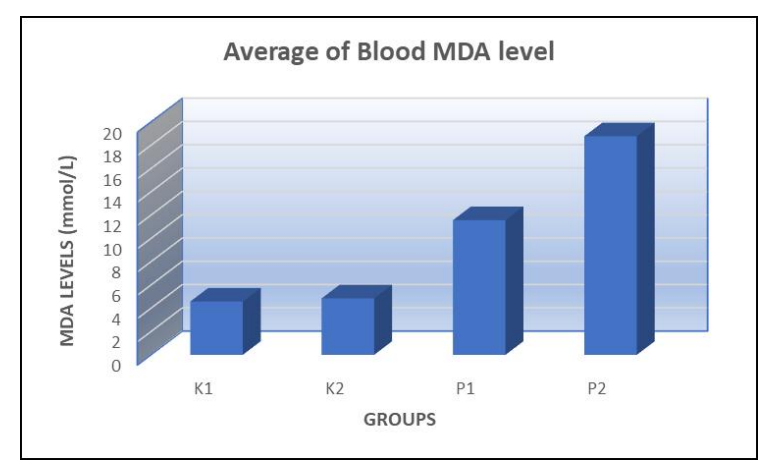

Figure 1. Mean MDA level
Blood MDA levels of rats for each group based on the Mann Whitney $U$ test are shown in table 2. The test results showed that there were significant differences in blood MDA levels between groups P2 with $\mathrm{P} 1, \mathrm{~K} 2$ and $\mathrm{K} 1$.

Table 2. Blood MDA levels of rats based on the Mann Whitney U test

\begin{tabular}{ccccc}
\hline Group & K1 & K2 & P1 & P2 \\
\hline K1 & - & 0,636 & $0,001^{*}$ & $0,001^{*}$ \\
K2 & 0,636 & - & $0,002^{*}$ & $0,001^{*}$ \\
P1 & $0,001^{*}$ & $0,002^{*}$ & - & $0,035^{*}$ \\
P1 & $0,001^{*}$ & $0,002^{*}$ & - & $0,035^{*}$ \\
P2 & $0,002^{*}$ & $0,001^{*}$ & $0,035^{*}$ & \\
\hline${ }^{*}$ p $<0,05$ & & & &
\end{tabular}

Based on the data obtained it was found that significantly the blood MDA levels in the group given electronic cigarette exposure were higher than in the group without exposure. This shows that electronic cigarettes cause blood MDA levels in the treatment group $(\mathrm{P})$ to increase compared to the control group $(\mathrm{K})$.

Electronic cigarette aerosols contain hazardous and non-hazardous chemicals. These include propylene glycol (PG), nicotine, flavorings, and vegetable glycerin (VG) in the form of drops and gases (Alexander et al., 2015). The content of electronic cigarettes which is a major contributor in the formation of free radicals is propylene glycol (Bitzer et al., 2018).

Another name for propylene glycol (PG) is 1,2-dihydroxypropane; methyl glycol; 1,2-propanediol; and trimethyl glycol. Propylene glycol is a colorless, clear, syrup-like liquid at room temperature. Propylene glycol has no odor and taste. Propylene glycol as a humectant is often used in industry. The paint and plastic industry uses PG as a solvent for food color and taste ((Bitzer et al., 2018)). 
Free radicals are molecular species capable of living independently that have unpaired electrons in their atomic orbitals. Many radicals are very reactive and can donate one electron to or extract electrons from other molecules. This relationship is referred to as an oxidant or reducing agent. This high reactivity causes most radicals to have very short half-lives (6-10 seconds or less) in biological systems, although some species can last longer (Young and Woodside, 2001). Free radicals are very reactive with polyunsaturated fatty acids that cause lipid peroxidation. Free radicals will react with polyunsaturated fatty acids such as AA, DHA and EPA produces thyobarbituric reactive acid (TBARS). Thiobarbituric reactive acid (TBARS) is an indicator often used to detect oxidative stress. Free radicals contained in electronic cigarette will cause oxidative stress (Bitzer et al., 2018).

The imbalance of reactive oxygen species (ROS) with total antioxidant capacity (TAC) causes oxidative stress (Sahu, Varma and Kachhawa, 2015). Lipids damage is directly caused by high reactive oxygen species (ROS). Two forms of ROS that strongly influence lipids are hydroxyl radicals (HO) and hydroperoxyls $\left(\mathrm{HO}_{2}\right)$. Oxidative cell damage is caused by hydroxyl radicals. This is because hydroxyl radicals specifically damage biomolecules and cause interference with cells such as cancer, nerve degeneration, and disorders of the cardiovascular system. Which plays an important role in lipid peroxidation is a hydroxyperoxyl radical. (Ayala, Muñoz and Argüelles, 2014). When oxidative stress occurs, TAC decreases, free radicals increase, causing lipid peroxidation, DNA damage, and cell death (Khajehnasiri et al., 2013).

Lipid peroxidation occurs due to membrane damage and aldehyde formation such as MDA caused by free radicals
(Khajehnasiri et al., 2013). There are three stages of lipid peroxidation. The first stage, known as initiation, is where a reactive oxygen attack occurs that is able to extract hydrogen atoms from the methylene lipid group due to a weak double bond. The second stage is propagation, in which the reaction of radical fatty acids with oxygen produces peroxyl lipid radicals (ROO). Lipid peroxyl radicals cause other hydrogen atoms to separate from nearby fatty acid molecules, thus forming fatty acid radicals. If this propagation reaction is continue it will cause peroxidation the unsaturation membrane lipid. Lipid peroxyl radicals can become lipid hydroperoxides which can then be decomposed into aldehydes or form cyclic, isoprotan, and hydrocarbon endoperoxides. The third stage is the chain breaking occurs after the interaction of one ROO with other radicals or antioxidants (Engwa, 2018). Lipid peroxidation produces oxidation products. The main product is lipid hydroperoxide (LOOH). The secondary product is an aldehyde. Aldehydes formed include 4-hydroxynonenal (4-HNE), propanal, malondialdehyde (MDA), and hexanal. Lipid peroxidation produces the most mutagenic product, malondialdehyde. The lipid peroxidation biomarker that is often used is malondialdehyde because it easily reacts with thiobarbituric acid (TBA). The thiobarbituric acid reacting substances test (TBARS) is based on the MDA reaction to TBA to produce a chromogen fluorescent red adduct color. The best marker of oxidative stress is malondyaldehyde because it has a high reactivity and toxicity (Ayala, Muñoz and Argüelles, 2014). The final product of lipid peroxidation can cause DNA damage. DNA damage can occur due to reactive bifunctional intermediates produced by the reaction of reactive aldehyde DNA with base DNA. The final product of lipid peroxidation due to oxidative stress is HNE, MDA, acrolein, and crotonaldehyde. These 
products will modify DNA bases, produce promutagenic lesions and stimulate gene mutations and cancer formation. Some of these products (MDA and HNE) cause protein damage to the lysine amino group, the cysteine sulfhydryl group, and the group's imidazolk histidine. Protein modification by aldehydes causes transcription factor disorders, contributes to neurodegenerative disorders, and kinase activation. Oxidative stress plays a role in various bodily disorders that occur such as inflammation, tumor formation, and degenerative diseases, as well as many other disturbing phenomena (Catala et al., no date). Peroxyl radicals from hydroperoxides with homoallylic cis-double bonds in the peroxyl group undergo cyclization by adding intramolecular radicals to the double bonds to form new radicals. The Intermediate free radicals are produced as a result of cyclization which will continuously form bicyclic endoperoxide. Prostaglandins are structurally related to bicyclic endoperoxide. The bicyclic endoperoxide subsequently cleaves to form MDA. Further reaction to the bicyclic endoperoxide produces MDA due to the non-enzymatic oxygen free radical reaction. The main precursor of bycyclic endoperoxide is AA. Enzymatic metabolism or reaction with proteins and cellular tissues from MDA that is formed will trigger the addition of DNA resulting in biomolecular damage. Oksidasi dan dekarboksilasi dehidrogenase aldehida berperan dalam metabolisme biokimia MDA. Asetaldehida yang diproduksi dalam proses dekarboksilasi selanjutnya oleh aldehidadehidrogenase dioksidasi menjadi asetat, $\mathrm{CO} 2$ dan $\mathrm{H} 2 \mathrm{O}$. Phosphoglucoseisomerase, on the other hand, plays a role in the MDA cytoplasmic metabolism to methylglyoxal (MG) and subsequently to D-lactate by the glyoxalase enzyme using GSH as an acofactor. MDA excretion in urine in the form of enaminals (RNH-CH-CH-CHO). Some examples of these enaminals are serine N-2- (propenal and N-epsilon- (2-propenal) (Ayala, Muñoz and Argüelles, 2014).

This study is in line with research Suryadinata et al. (2019), Stratton et al. (2018), and Ferkol et al (2018). Suryadinata (2019) examines the danger of electronic cigarette aerosol in the respiratory system, especially the lungs because electronic cigarette aerosol causes free radicals in the body to increase. Free radicals that are formed will bind oxygen and form Reactive Oxygen Species (ROS). Free radicals that increase excessively in the body can cause disturbance of the antioxidant balance in the body, so that it can cause oxidative stress. Exposure to electronic cigarette smoke adversely affects the airway. Even an increase in free radicals can cause respiratory diseases such as Chronic Obstructive Pulmonary Disease (COPD) (Suryadinata $e t$ al., 2019). Stratton (2018) examines that electronic cigarette can produce both of highly reactive ROS and more stable ROS to users during use. ROS is formed when activating electronic cigarette heating elements and the process of converting liquid into aerosols, so that ROS can enter directly from the device into the lungs. The age of the heating element also influences the formation of this ROS. Ion lithium battery electronic cigarette devices can also produce oxidants. Puffs of electronic cigarette produce free radicals at $3.3 \mathrm{~V}$ as many as 2.5 $\times 1013$ to $10.3 \times 1013$ radicals per puff (National Academies of Sciences, Engineering, and Medicine, 2018). Ferkol (2018) examines that electronic cigarettes produce dangerous vapors. Exposure to electronic cigarette vapor in the mouth and lung cells can cause DNA damage (Ferkol et al., 2018).

Based on the above analysis, it can be said that the increase in blood MDA levelss in the treatment group (P) is caused by 
oxidative stress triggered by electronic cigarette exposure.

The data obtained also shows that there are significant differences between groups P2 and P1. Data of P2 group who were given exposure to electronic cigarette as much as 30 spray was significantly higher than group $\mathrm{P} 1$ who were given exposure as much as 15 times spray of electronic cigarette. These data are in line with Bitzer's research that increasing $P G$ content will increase lipid oxidation markers (Bitzer et al., 2018). This shows that there is a linear relationship between electronic cigarette exposure with MDA levels, where the increasing number of electronic cigarette exposure causes an increase in MDA levels in the blood so that the risk of oxidative stress also increases.

\section{CONCLUSIONS}

Based on data analysis and discussion it can be concluded:

1. Electronic cigarettes cause oxidative stress so that the MDA levels of the treatment group increase significantly compared to the control group.

2. Blood MDA levels between groups given 30 sprays compared with groups given 15 electronic cigarette sprays were significantly different.

Based on the conclusions above, some suggestions are given as follows:

1. Electronic cigarette users are advised to reduce the consumption of electronic cigarette and even stop smoking, because smoking can cause oxidative stress as mentioned above. Electronic cigarette users are expected to increasingly understand the dangers of using electronic cigarette. This research also refutes the understanding that electronic cigarette can be used as a substitute for tobacco cigarette, because electronic cigarette are also dangerous for its users.

2. Health workers can use this research as a reference counseling and education to stop smoking both for students and public.

3. Further research can develop other research models with broader variables. Researcher can examine the clinical impact of the use of electronic cigarette and even appropriate therapies to reduce and or treat the effects of electronic cigarette for users.

\section{ACKNOWLEDGEMENT}

Thank you to all leaders of the Universitas Ciputra in particular from the Head of the Faculty of Medicine at the Universitas Ciputra, who has supported and facilitated the implementation of this research. Thank you to all academic community of the Faculty of Medicine at Universitas Ciputra, who have supported this research. Thank you to the Staff of Biochemistry Laboratory and Anatomical Pathology Laboratory, Faculty of Medicine, Universitas Airlangga for helping with this research.

\section{REFERENSI}

Alexander, L. E. et al. (2015) 'Electronic cigarettes: The new face of nicotine delivery and addiction', Journal of Thoracic Disease, 7(8), pp. E248E251. doi: 10.3978/j.issn.20721439.2015.07.37.

Artha, L. P. W. and Kusuma, M. A. P. (2017) Karakteristik Remaja Lakilaki Pengguna Rokok Elektronik di Kota Denpasar Tahun 2017, 4th Indonesian Conference on Tobacco or Health 2017. Jakarta. Available at: http://ictoh-

tcscindonesia.com/wpcontent/uploads/2018/01/ProceedingBook-4th-ICTOH.pdf. 
Ayala, A., Muñoz, M. F. and Argüelles, S. (2014) 'Lipid peroxidation:

Production, metabolism, and signaling mechanisms of malondialdehyde and 4-hydroxy-2nonenal', Oxidative Medicine and Cellular Longevity, 2014. doi: $10.1155 / 2014 / 360438$.

Bitzer, Z. T. et al. (2018) 'Effect of flavoring chemicals on free radical formation in electronic cigarette aerosols', Free Radical Biology and Medicine, 120, pp. 72-79. doi: 10.1016/j.freeradbiomed.2018.03.02 0.

Catala, A. et al. (no date) Lipid peroxidation.

Damayanti, A. (2016) 'Penggunaan Rokok Elektronik di Komunitas Personal Vaporizer Surabaya', Jurnal Berkala Epidemiologi, 4(2), pp. 250-261. doi: $\quad 10.20473 /$ jbe.v4i2.2016.250 261.

Devhy, N. L. P. and Yundari, A. . I. D. H. (2017) 'Faktor Yang Berpengaruh Terhadap Perilaku Merokok Konvensional dan Elektrik Pada Remaja Di Kota Denpasar', Bali Medika Jurnal, 4(2), pp. 63-72.

Ediana, D. (2016) 'Faktor-Faktor Yang Berhubungan Dengan Perilaku Merokok Di Dalam Rumah Di Kelurahan Tarok', Human Care Journal, $\quad$ (1). doi: 10.32883/hcj.v1i1.163.

Engwa, G. A. (2018) 'Free Radicals and the Role of Plant Phytochemicals as Antioxidants Against Oxidative Stress-Related Diseases', Phytochemicals - Source of Antioxidants and Role in Disease Prevention, (November). doi: 10.5772/intechopen.76719.

Ferkol, T. W. et al. (2018) 'Electronic cigarette use in youths: A position statement of the Forum of
International Respiratory Societies', European Respiratory Journal, 51(5). doi: 10.1183/13993003.00278-2018.

Grana, R. A. (2013) 'Electronic cigarettes: A new nicotine gateway?', Journal of Adolescent Health. Elsevier Inc., 52(2), pp. 135-136. doi: 10.1016/j.jadohealth. 2012.11.007.

Hajek, P. et al. (2014) 'Electronic cigarettes: Review of use, content, safety, effects on smokers, and potential for harm and benefit', Addiction., 109(11), pp. 1801-1810. doi: 10.1111/add. 12659.

Khajehnasiri, F. et al. (2013) 'Total antioxidant capacity and malondialdehyde in depressive rotational shift workers', Journal of Environmental and Public Health, 2013. doi: 10.1155/2013/150693.

National Academies of Sciences, Engineering, and Medicine, - (2018) Public Health Consequences of Ecigarettes., Public Health Consequences of E-cigarettes. Edited by K. Stratton, L. Y. Kwan, and D. L. Eaton. Washington, DC: The National Academies Press. doi: $10.17226 / 24952$.

Putra, I. G. N. E. et al. (2018) Gambaran Pemahaman, Persepsi, dan Penggunaan Rokok Elektronik pada Siswa Sekolah Menengah Atas di Kota Denpasar, Proceeding Book 4th ICTOH.

Qasim, H. et al. (2017) 'Impact of electronic cigarettes on the cardiovascular system', Journal of the American Heart Association, 6(9). doi: 10.1161/JAHA.117.006353.

Sahu, A., Varma, M. and Kachhawa, K. (2015) 'A Prognostic Study of MDA , SOD and Catalase in Breast Cancer Patients', 4(5), pp. 2013-2015.

Suryadinata, R. et al. (2019) 'the Effects of 
Exposure Duration To Electronic Cigarette Smoke on Differences in Superoxide Dismutase and Malondialdehyde in Blood of Wistar Rats', International Journal of Current Pharmaceutical Research, pp. 13-16. doi: 10.22159/ijcpr.2019v11i3.34084.

U.S. Department of Health and Human Services, - (2016) E-Cigarette Use Among Youth and Young Adults: A Report of the Surgeon General. Available at: https://doi.org/10.17226/24952.

Young, I. and Woodside, J. (2001) 'Antioxidants in health and disease', J Clin Pathol, 54(176), pp. 176-186. doi: $10.1136 /$ jcp.54.3.176. 